\title{
Geological and Engineering Properties of Granite Rocks from Aqaba Area, South Jordan
}

\author{
Jamal Abuqubu', Reyad A. Al Dwairi², Nafeth A. Hadi ${ }^{3}$, B. Merkel ${ }^{4}$, V. Dunger ${ }^{4}$, \\ Hamza A. Laila 1 \\ ${ }^{1}$ Ministry of Energy and Mining, Amman, Jordan \\ ${ }^{2}$ Department of Natural Resources and Chemical Engineering, Tafila Technical University, Tafila, Jordan \\ ${ }^{3}$ Department of Civil Engineering, Al-Balqa Applied University, Amman, Jordan \\ ${ }^{4}$ Bergaakademie Freiberg Technical University, Freiberg, Germany \\ Email: reyadn@hotmail.com
}

Received 20 October 2015; accepted 11 January 2016; published 14 January 2016

Copyright (C) 2016 by authors and Scientific Research Publishing Inc.

This work is licensed under the Creative Commons Attribution International License (CC BY).

http://creativecommons.org/licenses/by/4.0/

(c) (i) 0pen Access

\section{Abstract}

Jordanian granitic rocks (JG) are highly distributed and available in huge quantities in south Jordan, Aqaba area. Granite in south Jordan (JG) is belonging to Aqaba granite complex. This study has been carried out to investigate geological and engineering properties of JG from Aqaba vicinity, south Jordan, in addition to identify and classify the different granitic rocks. 27 random samples of JG were collected from different quarries in three locations from the study area to investigate their characterization. Engineering properties of JG were tested and investigated using ultra sonic velocity test, abrasion test, flexural strength, specific gravity test, and compressive strength test. Engineering tests results show that JG has metal disk abrasion less than $21 \mathrm{~mm}$, flexural strength of $16.9 \mathrm{Mpa}$, average dry specific gravity of 2.69 and very low absorption while the compressive strength results range between 60 to $90 \mathrm{Mpa}$. The results show that the engineering characterization of JG is complying with local and international specifications and standards used for classifying the decorative and building granite stones.

\section{Keywords}

Granite Rocks, Aqaba Area, Building Stones, Engineering Properties 


\section{Introduction}

Huge sources of granite and granodiorite rocks are distributed over random spots in Agaba complex, southern part of Jordan. These rocks are characterized by their high quality and economical value due to utilization of these rocks as ornamental, building stone, cladding and tiles. Identification of basement rocks was carried out by [1] and [2].

Comprehensive geological studies were evaluated by [3] and [4]. [5] had published the first geological map of Trans Jordan. [6] developed the first detailed studies on the basement rocks, defined the Aqaba Granite Complex, and published three scale maps of 1:250,000 for the Transjordan Rift to accompany the first comprehensive report on the geology of Jordan by [3].

German Geological Mission (GGM) [7], produced geological maps of scale 1:100,000 for South-West Jordan, where six sub-units of the crystalline basement rocks were characterized. First detailed studies were carried out by [8] for plutonic rocks of the general area of Aqaba.

[9] presented in three maps of scale 1:25,000 plutonic rocks of Aqaba area, Urf Mountain, Yutum Valley and Shoquera Mountain. [10] made an attempt to draw preliminary draft map at a scale of 1:50,000 for Aqaba Granite area and Alqoirh.

The summary of the overall geology of the basement rocks of Precambrian has published [7].

The geochemical studies of the basement rocks of Aqaba was performed in the years 1968-1969, particularly in the southeast of Aqaba, and followed the other geochemical surveys in 1970 in the east and north-east of Aqaba.

During the years 1992-1994 geochemical surveys were conducted for Aqaba complex and Wadi Araba through a joint venture between the Natural Resources Authority (NRA) and the French company (BRGM) in 1994 [11]. Final report has included surveys over the entire basement exposed in South Jordan-the far north of the Arabian-African Shield.

The geophysical studies were conducted on the basement rocks in South Jordan by aerial geophysical survey (magnetic, electromagnetic and radioactive) by two Canadian companies (Phoenix Corporation and Geoterrex Limited) during the years 1979 and 1980. The geochemical studies of the basement rocks of Aqaba were performed in the years 1968-1969, particularly in the southeast of Aqaba, and followed the other geochemical surveys in 1970 in the east and north-east of Aqaba.

During the years 1992-1994 geochemical surveys were conducted in Aqaba complex and Wadi Araba through a joint venture between the NRA and the French company BRGM has included surveys over the entire basement exposed in South Jordan-the far north of the Arabian-African Shield [12].

The huge quantities JG, low cost, high quality, and the lack of information about their geological and engineering properties, in addition to the expected future planning to use JG in civil engineering applications, have encouraged the authors to carry out this research work. This study aims at investigating and characterizing JG.

\section{Geology of Aqaba Complex}

\subsection{Study Area}

The study area is located in the extreme southern part of Jordan between the (35 - 35.25 PG) Latitude and (29.50 - 29.75 PG) Attitude, at a distance of about $280 \mathrm{~km}$ from Amman.

The map area is uninhabited except the city of Aqaba and a few villages and Bedouin communities along the main street linking Amman-Ma’an-Aqaba (Figure 1).

The study area is accessible through Amman-Ma'an-Aqaba highway or The Dead Sea-Wadi Araba road.

The map area is characterized by gentle to rough terrain, accessed by desert routs. The climate is hot in summer and relatively moderate in winter, the annual temperature ranges between $32^{\circ} \mathrm{C}$ and $15.7^{\circ} \mathrm{C}$ respectively. The average annual rainfall during the winter season is $32 \mathrm{~mm}$. The average annual relative humidity is ranging from $39 \%$ in summer to $57 \%$ in winter.

Climate reflects the vegetation in the study area; this region lacks vegetation except for a few weeks where pastoral grows for a short time of spring days, or some few shrubs and trees that grow in the open valleys.

The region is characterized by the presence of two distinct areas, a mountainous topography with severe to moderate slopes where the target granite rocks are mainly located. The second region corresponding to the parallel Rift Valley to the west of the study area. 


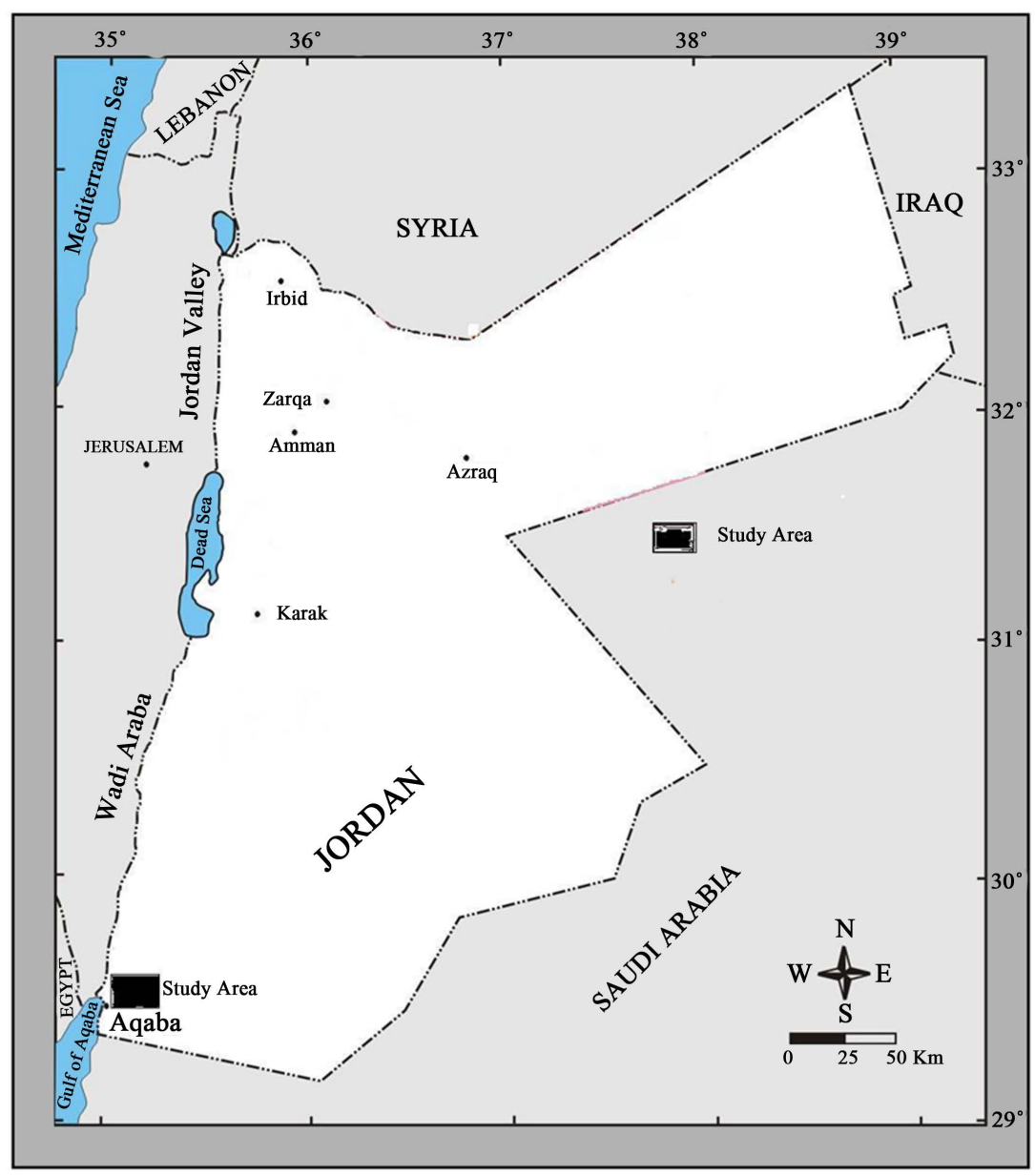

Figure 1. Distribution of the Aqaba complex granitic rocks.

The study area is considered as a part of the southern highlands of the Kingdom, altitudes ranges from $(0.00)$ meters above sea level at the Gulf of Aqaba to (1590) meters above sea level in the northern part of central part of the map in Mount Almiahi. The dominant rocks in the area are crystallized granite rocks and present as a series of rugged mountains, hills, and scattered undulating hills separated by a flat and broad valleys. Abundant alluvial fans are available and reflect the tectonic activity along the fault of the Dead Sea on the Jordanian side.

\subsection{Geological Setting}

The pre-Cambrian granite rocks, representing the Arabian-Nubian Shield exposed in the north-west of the Arabian Peninsula and Jordan, where it ends at 30 km's north of the Gulf of Aqaba on the west shoulder of the Wadi Araba, and along the eastern side of the Wadi Araba they constitute the mountains between Aqaba and Alqoirh in the north-east part through, Wadi Al Yutum, even disappear completely near the bottom of the Qa'a Al Disi area. It can be seen in Wadi Rum under majestic sandstone mountains.

Granite rocks are exposed in Wadi Araba near Qa'a Al Saadien and opposite area of BerMathkor, Fidan area, Wadi Dana and east Ghor Safi near the Arab Potash Company. This is the extreme outcropping of the Arabian-Nubian Shield in the north.

The conducted detailed studies of the basement rocks by the Natural Resources have divided these rocks to two main categories:

The basement rocks were divided into two categories, oldest Aqaba Complex and recent Araba Complex according to detailed and comprehensive studies carried out by [13] and [14].

The two divisions are separated by a regional unconformity surface with an estimated age of about 600 million years, while the Araba complex age extends up to 540 million years. 


\subsection{Structural Geology and Geomorphology}

The Dead Sea rift primarily directed towards the north and northwest is located to the west of the study area, which is part of the Arab-African Rift Valley stretching from North Africa to southern Turkey along a distance reaches more than $1000 \mathrm{Km}$.

There are two main faults in the study area; one towards the north-south and the other towards the northwest-southeast, where the most important geological structures of these faults is the Heights Mountains of Al Rashidiya. There are a number of faults and joints associated with these major faults with a general direction trend towards the west.

\section{Types of Granite Rocks in the Aqaba Map Area}

\subsection{Al Yutum Group}

The Granite of this group is the most recent age and ranges from coarse to fine grain size, the prevailing Biotite Granite Abu Jeddah, a rough equilateral grained which ranges in composition from Monzogranite to syenogranite which is distinguished from Omran Monzogranite by its color and presence of hornblende in the latter. The youngest unit in this family is Hamrat Granite and is outcroping at the edge of Abo Jaddah plutonic rocks ranging in composition from Cenogranite to alkali feldspar granite.

\subsection{Al Molgan Monzogranite/Al Urf Granite Rocks}

This period characterized by dykes and sills consisting of Almleghan Monzogranite rocks and porphyritic Urf family, although they were separated from each other on the map, but they are linked with each other and there is a strong correlation between the two rock types with no sharp lines break them and most probably they have the same age. The Almleghan unit is a white Biotite Monzogranite soft to medium grain size, but the Porphyry Urf is a Granodiorite. Monzogranite has large crystals of feldspar, which varies on a regular basis in the rock matrix, and the medium particle size resembles those found in Almleghan Monzogranite.

\section{Materials and Methods}

\subsection{Material and Sampling}

Geological and satellite maps were used to locate the promising sites in the study area. Bulk samples with dimensions of nearly $20 \times 20 \times 50 \mathrm{~cm}$ ) were collected from different sites. Three locations were chosen for sampling Abu Jeddah, Hamrat granite and Urf granite. The samples from Abu Jeddah were nominated as AJ1, AJ2, etc. The samples from Hamrat granite were labeled as H1, H2, H3, etc. Samples from Urf granite were labeled as U1, U2 etc. The coordinates for each sample was obtained utilizing the Global positioning system (GPS) device. Coordinates were projected on the related geological map (Table 1).

\subsection{Engineering Properties and Testing}

Engineering properties studies were conducted on (27) samples of granite rocks distributed to all the different study sites, as shown in the attached map in Figure 2. Cylindrical core samples with 1/d = 2 were obtained utilizing 2.5 inch diameter electrical core machine at NRA laboratories. Rectangular samples were also cut with 5 cm depth $\times 5 \mathrm{~cm}$ width $\times 30 \mathrm{~cm}$ length utilizing electrical stone cutting machine. Digital compressive strength machine type (Type: ADR-manufactured by ELE), $100 \mathrm{KN}$ capacity was used. Flexural strength for the rectangular samples was determined using $50 \mathrm{KN}$ capacities (IFRAME 70-T0108/E, Controls). The samples were awed and subjected to surface and polishing as needed before testing. The following tests were carried out according to the indicated standard.

1-Specific Gravity according to ASTM C97M-09 [15].

2-Absorption according to ASTM C97M-09.

3-Metal Disc Abrasion according to BS EN 12808-2-2008 [16].

4-Unconfined Compressive Strength according to ASTM C170 [17].

5-Flexure Strength according to ASTM C880 [18].

6-Ultra sonic pulse velocity according to ASTM D2845 [19]. 


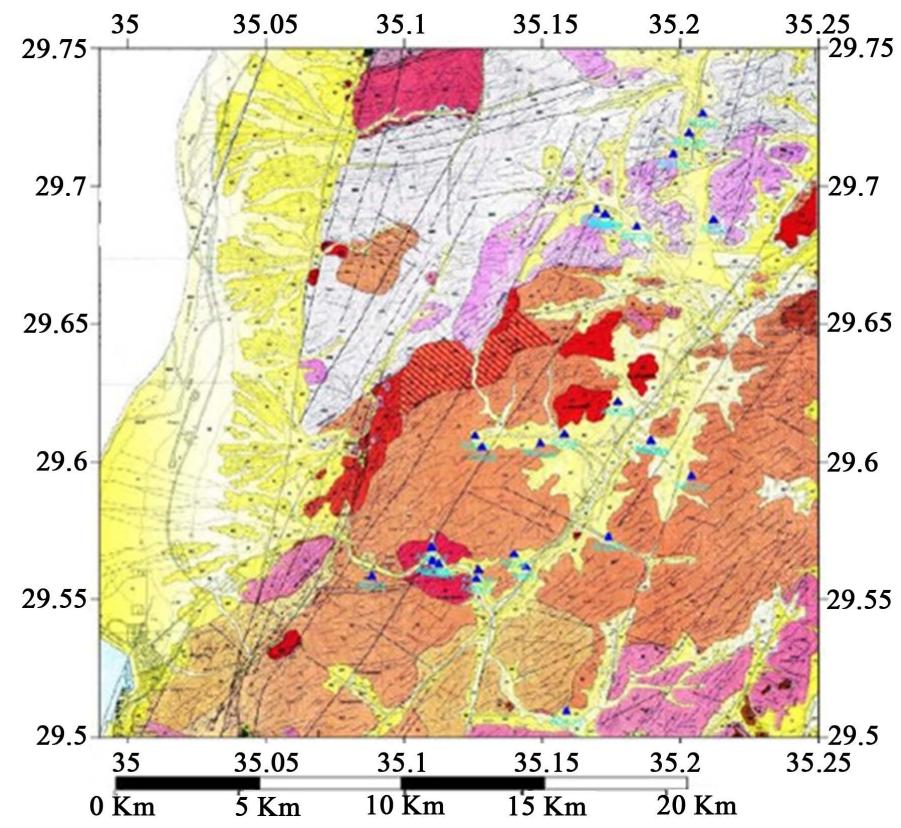

Figure 2. Geologic map of Aqaba granite complex, sampling location.

Table 1. Location of south Jordan sampling sites.

\begin{tabular}{|c|c|c|c|}
\hline Location & Sample name & & \\
\hline \multirow{14}{*}{ Abu Jeddah granite } & AJ1 & Easting & Northing \\
\hline & AJ2 & 35.14 & 29.56 \\
\hline & AJ3 & 35.14 & 29.57 \\
\hline & AJ4 & 35.09 & 29.56 \\
\hline & AJ5 & 35.13 & 29.61 \\
\hline & AJ6 & 35.13 & 29.61 \\
\hline & AJ7 & 35.16 & 29.61 \\
\hline & AJ8 & 35.21 & 29.69 \\
\hline & AJ9 & 35.21 & 29.73 \\
\hline & AJ10 & 35.17 & 29.69 \\
\hline & AJ11 & 35.17 & 29.69 \\
\hline & AJ12 & 35.13 & 29.56 \\
\hline & AJ13 & 35.11 & 29.57 \\
\hline & AJ14 & 35.17 & 29.69 \\
\hline \multirow{7}{*}{ Hamrat granite } & H1 & 35.17 & 29.69 \\
\hline & $\mathrm{H} 2$ & 35.16 & 29.51 \\
\hline & Н3 & 35.2 & 29.6 \\
\hline & $\mathrm{H} 4$ & 35.17 & 29.57 \\
\hline & H5 & 35.22 & 29.62 \\
\hline & H6 & 35.26 & 29.57 \\
\hline & H7 & 35.2 & 29.72 \\
\hline \multirow{6}{*}{ Urf granite } & U1 & 35.13 & 29.56 \\
\hline & $\mathrm{U} 2$ & 35.18 & 29.69 \\
\hline & U3 & 35.18 & 29.62 \\
\hline & U4 & 35.2 & 29.71 \\
\hline & U5 & 35.15 & 29.61 \\
\hline & U6 & 35.11 & 29.56 \\
\hline
\end{tabular}




\section{Results and Discussions}

The geological classification of the different three main types of granite rocks, namely Abu Jeddah Granite rocks, Hamrat Granite and Urf Granite rocks are not complying with their engineering classification.

All three types fall within the same engineering classification despite the difference in their appearance, such as the variation in color, different particle size, crystal structure and chemical components, it still remains between the lower and the upper limits mentioned in the approved specifications in this research. Table 2 and Table 3 show the general classification of the granite rocks and the standards adopted for each class.

Table 2. The obtained results for different engineering properties of JG.

\begin{tabular}{|c|c|c|c|c|c|c|}
\hline Location & $\begin{array}{l}\text { Sample } \\
\text { name }\end{array}$ & $\begin{array}{l}\text { Specific } \\
\text { gravity }\end{array}$ & $\begin{array}{c}\text { Water } \\
\text { absorption \% }\end{array}$ & $\begin{array}{l}\text { Unconfined compressive } \\
\text { strength (MPa) }\end{array}$ & $\begin{array}{l}\text { Flexural strength } \\
\text { (MPa) }\end{array}$ & $\begin{array}{l}\text { Sound speed } \\
\mathrm{m} / \mathrm{s}\end{array}$ \\
\hline \multirow{14}{*}{$\begin{array}{l}\text { Abu Jeddah } \\
\text { granite }\end{array}$} & AJ1 & 2.6 & 0.62 & 70 & 14 & 4489 \\
\hline & AJ2 & 2.6 & 0.59 & 65 & 16 & 4391 \\
\hline & AJ3 & 2.62 & 0.35 & 62 & 15 & 5848 \\
\hline & AJ4 & 2.6 & 0.64 & 61 & 19 & 3792 \\
\hline & AJ5 & 2.62 & 0.13 & 75 & 20 & 4167 \\
\hline & AJ6 & 2.65 & 0.45 & 80 & 15 & 5000 \\
\hline & AJ7 & 2.65 & 0.56 & 59 & 16 & 5003 \\
\hline & AJ8 & 2.65 & 0.17 & 78 & 18 & 5757 \\
\hline & AJ9 & 2.66 & 0.29 & 64 & 16 & 5665 \\
\hline & AJ10 & 2.65 & 0.32 & 75 & 21 & 4665 \\
\hline & AJ11 & 2.62 & 0.31 & 92 & 17 & 4928 \\
\hline & AJ12 & 2.66 & 0.21 & 87 & 16 & 4481 \\
\hline & AJ13 & 2.64 & 0.28 & 90 & 19 & 4682 \\
\hline & AJ14 & 2.66 & 0.22 & 74 & 20 & 3992 \\
\hline \multirow{7}{*}{$\begin{array}{l}\text { Hamrat } \\
\text { granite }\end{array}$} & $\mathrm{H} 1$ & 2.63 & 0.26 & 66 & 14 & 3527 \\
\hline & $\mathrm{H} 2$ & 2.6 & 0.19 & 72 & 17 & 4391 \\
\hline & H3 & 2.6 & 0.25 & 80 & 16 & 3658 \\
\hline & $\mathrm{H} 4$ & 2.63 & 0.25 & 67 & 18 & 5327 \\
\hline & H5 & 2.65 & 0.2 & 78 & 16 & 4184 \\
\hline & H6 & 2.63 & 0.29 & 67 & 15 & 4107 \\
\hline & $\mathrm{H} 7$ & 2.64 & 0.24 & 65 & 17 & 4158 \\
\hline \multirow{6}{*}{ Urf granite } & U1 & 2.66 & 0.53 & 72 & 17 & 4188 \\
\hline & U2 & 2.64 & 0.63 & 83 & 16 & 3827 \\
\hline & U3 & 2.65 & 0.45 & 75 & 19 & 39040 \\
\hline & U4 & 2.66 & 0.39 & 65 & 18 & 4050 \\
\hline & U5 & 2.63 & 0.52 & 74 & 18 & 3950 \\
\hline & U6 & 2.62 & 0.55 & 79 & 16 & 4000 \\
\hline
\end{tabular}

Table 3. The general classification of the granite rocks and obtained average results.

\begin{tabular}{|c|c|c|c|c|c|c|}
\hline $\begin{array}{c}\text { Test } \\
\text { rock type }\end{array}$ & $\begin{array}{c}\text { Specific } \\
\text { gravity } \mathrm{G}_{\mathrm{SSD}}\end{array}$ & Absorption \% & $\begin{array}{l}\text { Unconfined compressive } \\
\text { strength (MPa) }\end{array}$ & $\begin{array}{c}\text { Flexure } \\
\text { strength (MPa) }\end{array}$ & $\begin{array}{c}\text { Metal disc } \\
\text { abrasion (mm) }\end{array}$ & $\begin{array}{c}\text { Sound } \\
\text { speed }(\mathrm{m} / \mathrm{s})\end{array}$ \\
\hline $\begin{array}{l}\text { Granite and } \\
\text { granodiorite }\end{array}$ & $\begin{array}{c}\geq 1.00 \\
\mathrm{Av}=2.63\end{array}$ & $\begin{array}{c}\leq 1.00 \\
\text { Av. }=0.36\end{array}$ & $\begin{array}{c}\geq 60.0 \\
\text { Av. }=73\end{array}$ & $\begin{array}{l}\geq 8.0 \\
\text { Av. }=17\end{array}$ & $\begin{array}{c}\text { Class A } \leq 21 \\
\text { Class B } 21.1-28 \\
\text { Class C } 28.1-33\end{array}$ & Av. $3000-6500$ \\
\hline
\end{tabular}


The results fall between 2.6 and 2.66. Variation of results is noticed for the three granite sources due to their minor variation in their mineralogical composition. The results are shown in Figure 3.

The absorption results of the Hamrat granite showed lower absorption value. In general all absorption results are vey low and considered advantageous. The results are shown in Figure 4.

Compressive strength in(Mpa) results of the investigated samples from different spots are shown in Figure 5.

Compressive strength resluts are satifactory for such rock type. It is clear that the compressive strength is not dependent on geological classification carried out by many researchrs. However, granite rock from any of the studied locations showed accepted strength results which satisfy the utilization of such rocks as dimensional and decorative stones for construction purposes.

The results of the Flextural strength $\left(\mathrm{N} / \mathrm{mm}^{2}\right)$ for the tested samples are shown in Figure 6 .

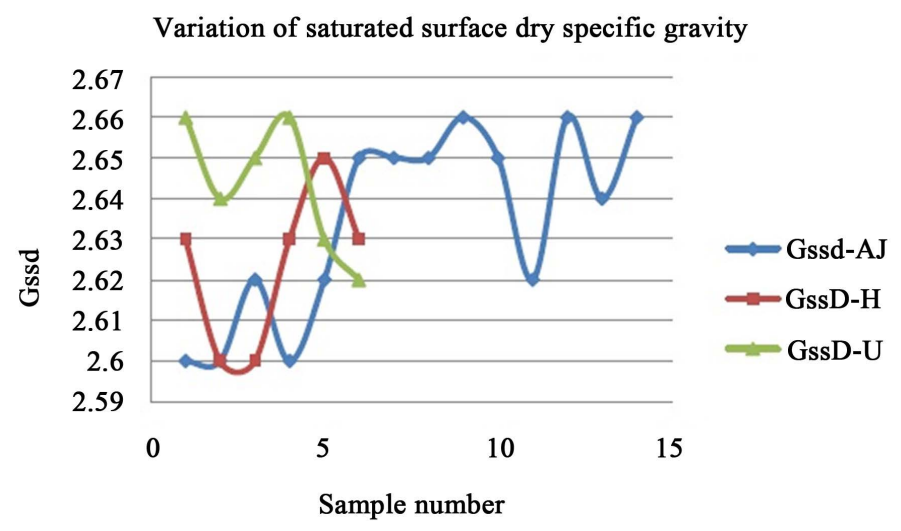

Figure 3. Variation of $\mathrm{G}_{\mathrm{SSD}}$ for granite samples.

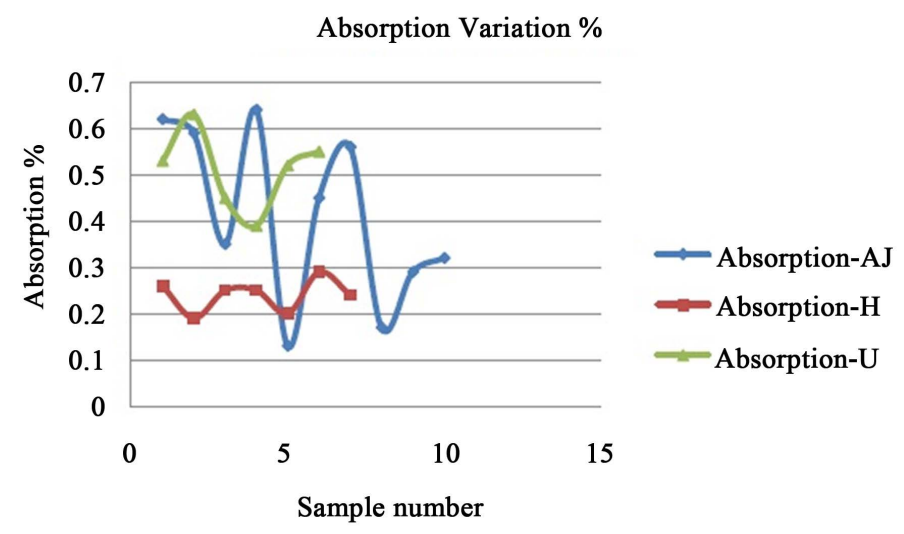

Figure 4. Absorption for granite from different locations.

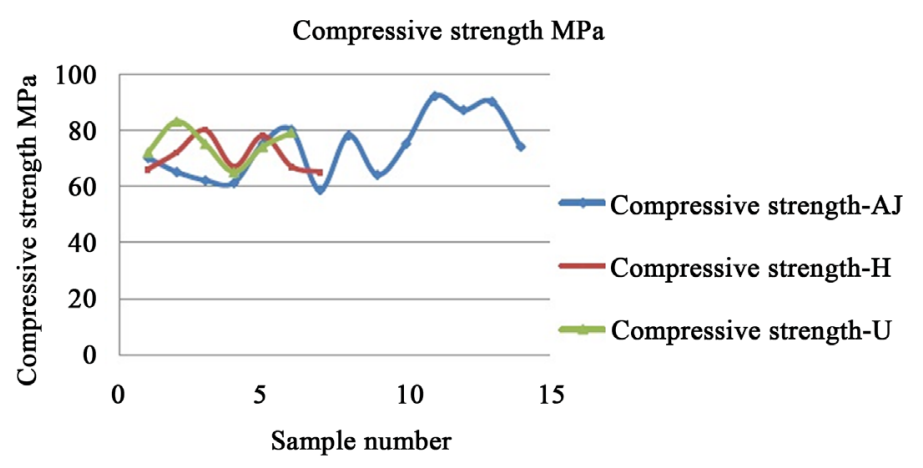

Figure 5. Compressive strength resluts for grnite samples. 


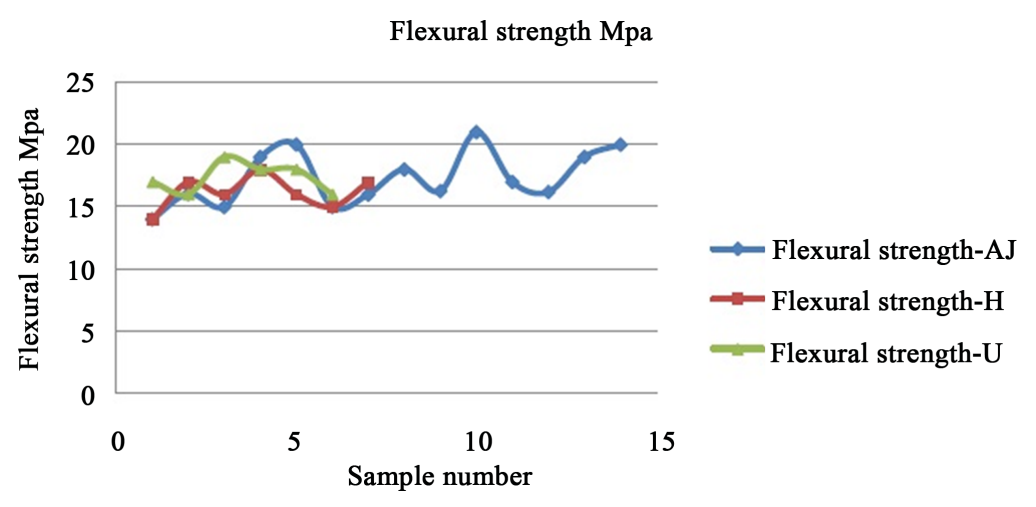

Figure 6. Flextural strength for the granite samples.

Rrectangular specimens were subjected to a three-point bending test to determine their flexural strength according to ASTM C880. For a rectangular sample with $L \times d \times b$ under a load in a three-point bending, flexural strength is calculated according to the following formula

$$
\sigma=\frac{3 F L}{2 b d^{2}}
$$

$\sigma=$ bending strength;

$F$ : the load (force) at the mid span of rectangular sample;

$L$ : the length of the support span;

$b$ : width of the sample;

$d$ : thickness of the sample.

The obtained resluts are corrolated with the direct destructive testing results obtained for the same samples. The results of pulse velocity as m/sec are shown in Figure 7.

Ultra sonic pulse velocity technique as a nondestructive testing is correlated with many physical and mechanical properties. The sonic pulse velocity increases with increasing density, compressive strength and the other strength parameters.

The results of Metal disk abrasion mm are shown in Figure 8.

This experiment is conducted to determine the erosion of the rock used in the paving and interfaces exposed to continuous friction factors and weathering, and is done using a metal disk spins perpendicular to the surface of parallel rectangle samples of dimensions $(10 \times 10 \times 2 \mathrm{~cm})$, where the sample surface is smooth and polished. Erosion of the sample is interpreted using the length of incision $(\mathrm{mm})$.

The result of the overall average for the entire collected samples are close to each other, thus confirms that all the three Granite types are similar in their properties gained from the laboratory tests. The studied sites can be considered as one unit according to their engineering properties in spite of three deferent units from the geological point of view.

The results indicate that all studied rock samples of Abu Jeddah Granite, Hamrat Granite and Urf Granite fall within the required specifications in terms of the specific gravity and the percentage of water absorption. These rocks have high densities and reflecting the hardness of these samples and compacted texture.

Given the results of metal disc abrasion test, it is obvious that all samples are within acceptable limits and confirming the fact of compacted texture and low porosity of all the tested samples.

The ultra sonic pulse velocity for all samples indicates a solid and compact texture even for the fine grained texture of the studied granite samples. All the results of the tested samples were fall between the maximum and the minimum acceptable values of similar granite types.

Variation of compressive and flexural strength results may be related to variations in texture and mineralogical composition of the tested samples from different locations. The overall low strength results could be related to the micro internal deformation in the granite masses in the study area caused by the ground movements due to dissected strike-slip fault which running along the Jordan Rift Valley. Intensive physical weathering due to the climate nature can be concluded since the samples were surficial. 


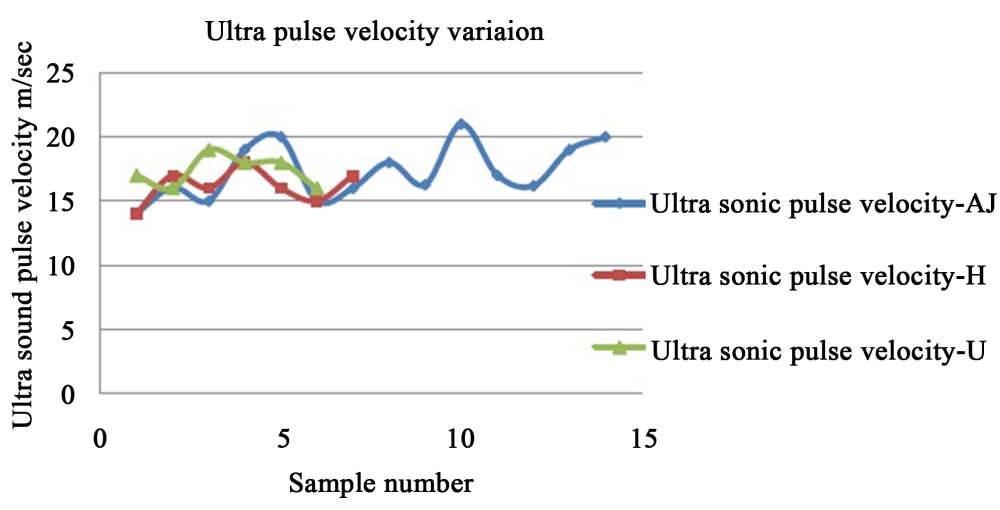

Figure 7. Ultra sonic pulse velocity for the granit samples.

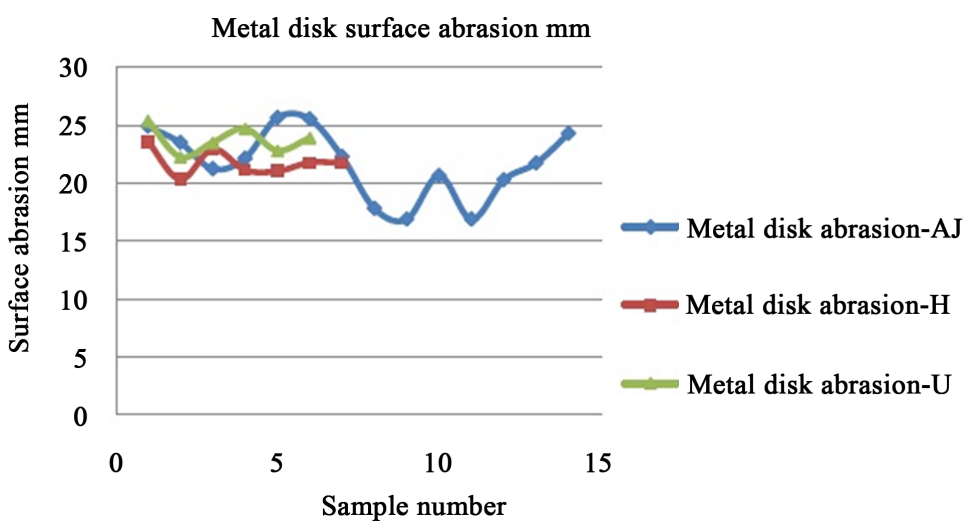

Figure 8. Metal disk abrasion values for granite.

\section{Recommendations}

1) Detailed geological and engineering properties of the different types of rocks in the vicinity of the study area are highly recommended.

2) Conduct core drilling to different depths to determine the depths affected by vertical and horizontal ground movement.

3) Conduct the necessary tests on samples taken from drilled boreholes to determine the mechanical, physical and chemical characteristics of those rocks.

\section{References}

[1] Blake, G.S. (1936) The Stratigraphy of Palestine and Its Building Stones. Printing and Stationary Office, Jerusalem, $133 \mathrm{p}$.

[2] Picard, L. (1941) The Precambrian of the North Arabian-Nubian Massif. Bulletin of the Geology Department, Hebrew University, Jerusalem, 3, 1-30.

[3] Burdon, D.J. (1959) Handbook of the Geology of Jordan. To Accompany and Explain the Three Sheets of the 1:250,000 Geological Map of Jordan East of the Rift by A.M. Quennel. Government of the Hashemite Kingdom of Jordan, 82.

[4] Bender, F. (1968) Geologie von Jordanien, Beitrage zur Regional Geologie der Erde. Band 7, Borntraeger. Berline. 230 p.

[5] Ionides, M.G. and Blake, G.S. (1939) Report on the Water Resources of Transjordan and Their Development. Incorporating a Report on Geology, Soils, Minerals and Hydrogeological Correlations. Crown Agents for the Colonies, London, $372 \mathrm{p}$.

[6] Quennel, A.M. (1951) The Geology and Mineral Resources of (Former) Transjordan. Colonial Geology and Mineral Resources, 2. 
[7] Bender, F. (1974) Geology of Jordan Contribution to the Regional Geology of the World. Gebrueder Borntraeger, Berlin, $196 \mathrm{p}$.

[8] Van den Boom, G. and Lahloub, M. (1964) Geological and Petrological Investigations of the Igneous Rocks in the Area of Quweira, South Jordan. Report German Geological Mission in Jordan, 12 p.

[9] Van den Boom, G. and Rosche, H. (1969) Modalbestand und petrochemie der granite von Aqaba-Quweira, SU djordanien. Beih Geol Jahrb, 81, 113-148.

[10] Hakkl, W. (1971) The Mineral Exploration of the Aqaba Granites. The Hashemite Kingdom of Jordan. Natural Resources Authority, Mineral Resources Division Report, 31 p.

[11] Final Report (1994) NRA/BRGM Project Staff. Geochemical and Mineral Exploration of Aqaba-Area Complex.

[12] French Geological Survey (BRGM) (1994) Geochemical and Mineral Exploration of Aqaba-Araba Complex Final Report. Economic Geology Project (EEC Project No. Sem/03/628/013). Natural Resources Authority, 209 p.

[13] McCourt, W.J. and Ibrahim, K.M. (1990) The Geology, Geochemistry and Tectonic Setting of the Granitic and Associated Rocks in the Aqaba and Araba Complexes of Southwest Jordan. The Hashemite Kingdom of Jordan, Natural Resources Authority, Geology Directorate, Amman.

[14] Rabba, A.I. and Ibrahim, M.K. (1988) Petrography of the Plutonic Rocks of the Aqaba Complex, Jordan. Bulletin 9, Geological Mapping Division, Natural Resources Authority, 86 p.

[15] American Society for Testing and Materials (ASTM) C97. Standard Test Methods for Absorption and Bulk Specific Gravity of Dimension Stone.

[16] British Standard European Norm (BS EN) 12808-2 (2008) Grouts for Tiles. Part 2: Determination of Resistance to Abrasion.

[17] American Society for Testing and Materials (ASTM) 170. Standard Test Method for Compressive Strength of Dimension Stone.

[18] American Society for Testing and Materials (ASTM) C880/C880M-09. Standard Test Method for Flexural Strength of Dimension Stone.

[19] American Society for Testing and Materials (ASTM) D2845. Standard Test Method for Laboratory Determination of Pulse Velocities and Ultrasonic Elastic Constants of Rock. 